\title{
FAKTOR YANG MEMPENGARUHI KONSUMEN TERHADAP KEPUTUSAN MEMBELI BUSANA MUSLIMAH MODERN
}

\author{
Khoirun Nisya \\ Akhmad Baidun \\ UIN Syarif Hidayatullah Jakarta \\ akhmad.baidun@uinjkt.ac.id
}

\begin{abstract}
This study aims to determine the factors that influence consumer buying decisions against modern muslim fashion by using logistic regression approach. The population in this study as many as 595 people, while a sample of more than 200 people were taken using nonprobability sampling technique. To measure the orientation purposes, the authors create their own measurement tool based on the theory Kotler dan Armstrong (2007). Confirmatory factor analysis is used to test the gauge and logistic regression analysis was used to test the research hypotheses. All testing techniques performed using SPSS and LISREL. The results showed that the dimensions of beliefs and attitudes of psychological factors infeluence the decision to buy a modern muslim fashion fit $(P>0.005)($ Chi-square $=21.86, d f=14, P$-value $=0.08146)$ and accounted for $38.4 \%$ of the variation in the table the regression coefficients of the six independent variable only one that sifnificantly influence the decision to buy the dimensions logit beliefs and attitudes of psychological factors ( $P$-value $<0.05)$.
\end{abstract}

Keywords: Consumer Behavior, Factor Social, Factor Psychological, Decision Buying

\begin{abstract}
Abstrak
Penelitian ini bertujuan untuk mengetahui faktor-faktor yang mempengaruhi konsumen terhadap keputusan membeli busana muslimah modern dengan menggunakan pendekatan regresi logistik. Populasi dalam penelitian ini sebanyak 595 orang sedangkan sampel berjumlah 200 orang yang diambil dengan menggunakan teknik nonprobability sampling. Untuk mengukur orientasi tujuan, penulis membuat sendiri alat ukur berdasarkan teori Kotler dan Armstrong (2007). Analisis faktor konfirmatorik digunakan untuk menguji alat ukur dan analisi regresi logistik digunakan untuk menguji hipotesis penelitian. Semua teknik pengujian dilakukan menggunakan SPSS dan LISREL. Hasil penelitian menunjukkan bahwa dimensi keyakinan dan sikap dari faktor psikologis mempengaruhi keputusan membeli busana muslimah modern fit $(P>0.05)$ (Chi-Square $=21.86, d f=14, \quad P$ value $=0.08146$ ) dan memberikan kontribusi sebesar $38.4 \%$ dari variasi keputusan membeli dalam satuan logit. Namun dilihat dari tabel koefisien regresi dari enam variabel independen hanya satu yang berpengaruh signifikan terhadap logit keputusan membeli yaitu dimensi keyakinan dan sikap dari faktor psikologis ( $P$-value $<0.05)$.
\end{abstract}

Kata Kunci: Perilaku Membeli, Faktor Sosial, Faktor Psikologis, Keputusan Membeli

Diterima: 3 November 2013 Direvisi: 30 November 2013 Disetujui: 9 Desember 2013 


\section{PENDAHULUAN}

Perkembangan industri fashion muslimah di tanah air mulai marak di kotakota besar di pulau Jawa sejak tahun 1990-an, namun baru dirasakan pada tahun 1995. Sejak saat itulah, semakin banyak perempuan Indonesia yang berbusana muslimah, bahkan busana khas ini telah menyebar ke berbagai perkantoran, hotel berbintang, sekolah, hingga pasar modern dan tradisional. Fashion muslimah di Indonesia memiliki ciri khas tertentu. Kolaborasi efektif antara pemerintah dan swasta dalam upaya mengoptimalkan potensi kekayaan budaya dan perancang busana diyakini akan menghasilkan produk yang inovatif dan produktif. Desain merupakan faktor yang sangat menentukan dalam peningkatan daya saing di dalam produk industri busana muslimah. Oleh karena itu, untuk memenangkan kompetisi pasar dalam maupun luar negeri, para pelaku usaha industri busana muslim harus memperkuat kreativitas untuk menuangkan ide baru (kemenperin.go.id).

Terlepas dari aturan agama dalam berbusana yang sesuai syar" $\mathrm{i}$, busana muslimah modern ini mangacu pada trend busana muslim yang sedang berkembang pesat saat ini. Dengan adanya fenomena hijab muslim di Indonesia khususnya di ibukota Jakarta, banyak bermunculan para desainer berbakat yang bersaing dalam menghasilkan kreativitas busana muslimah. Hasil kreasi busana muslimah yang mudah diperoleh dan terkenal dikalangan masyarakat yaitu, dari beberapa publik figur seperti Dian Pelangi, Ria Miranda, Adya Zaskia Mecca, Zaskia Sungkar, Jena Hara, dan lain-lain (republika.co.id, 2014).

Perkembangan fashion muslim yang begitu pesat, menjadikan timbulnya persaingan pasar dalam menarik minat konsumen untuk melakukan keputusan membeli. Konsumen akan menggunakan berbagai kriteria dalam membeli produk dan merek tertentu. Konsumen membeli produk yang sesuai kebutuhan, selera, dan daya beli. Konsumen tentu akan memilih produk yang bermutu dengan harga yang lebih murah. Konsumen membuat banyak keputusan pembelian setiap hari. Kebanyakan perusahaan besar meneliti keputusan membeli konsumen secara rinci untuk menjawab pertanyaan tentang apa yang dibeli konsumen, dimana konsumen membeli, bagaimana dan berapa banyak yang konsumen beli, kapan konsumen membeli, dan mengapa konsumen membeli. Pemasar dapat mempelajari pembelian konsumen yang sebenarnya untuk menemukan apa yang dibeli, dimana, dan berapa banyak (Kotler \& Armstrong, 2008). 
Keputusan membeli merupakan pemilihan suatu tindakan dari dua atau lebih pilihan alternatif, menurut Schiffman dan Kanuk (2002). Keputusan membeli oleh seorang konsumen terhadap suatu produk diawali dengan kesadaran pembeli akan adanya masalah kebutuhan. Konsumen menyadari bahwa terdapat perbedaan antara kondisi sesungguhnya dengan kondisi yang diinginkan. Hal ini mengakibatkan konsumen aktif mencari informasi yang lebih banyak untuk mengetahui produk yang diminati. Setelah memperoleh informasi dan melakukan evaluasi barulah seorang konsumen akan memutuskan untuk membeli suatu produk yang sesuai dengan keinginan dan kebutuhan. Sebelum keputusan tersebut diambil, seseorang akan dihadapkan pada suatu proses pengambilan keputusan yang terdiri dari pengenalan masalah, pencarian informasi, evaluasi alternatif, keputusan membeli dan perilaku pasca pembelian (Setiadi, 2008).

Penelitian terdahulu yang dilakukan oleh Feri Aditia Suhaji 2010 dengan judul "faktor-faktor yang mempengaruhi keputusan pembelian baju MINT di counter Java Mall". Variabel yang digunakan yaitu kebudayaan, kelas sosial, kelompok referensi, keluarga, pengalaman, kepribadian, sikap dan kepercayaan, serta konsep diri. Metode analisis yang digunakan yaitu regresi linier berganda. Hasil penelitian menunjukkan bahwa faktor-faktor kebudayaan, sosial, pribadi dan psikologis mempengaruhi keputusan pembelian baju MINT di counter Java Mall. Penelitian selanjutnya dilakukan oleh Yohanes Suhari (2008) yang berjudul keputusan membeli secara online dan faktor-faktor yang mempengaruhinya (studi kasus produk e-Marketplace). Variabel yang digunakan yaitu kekuatan sosial budaya (faktor budaya, tingkat sosial, kelompok panutan, dan keluarga) dan kekuatan psikologis (pengalaman belajar, kepribadian, sikap dan keyakinan, serta gambaran diri). Alat analasis yang digunakan adalah regresi linier berganda. Hasil penelitian menunjukkan bahwa faktor-faktor keputusan pembelian dipengaruhi oleh kekuatan sosial budaya (faktor budaya, tingkat sosial, kelompok panutan, dan keluarga) dan kekuatan psikologis (pengalaman belajar, kepribadian, sikap dan keyakinan, serta gambaran diri).

W.J. Stanton (1984) mengemukakan bahwa pasar adalah orang yang mempunyai keinginan untuk puas, mempunyai uang untuk belanja dan mempunyai kemauan untuk membelanjakannya. Dari kedua defenisi tersebut dapat dikemukakan tiga faktor yang tercakup di dalamnya, yaitu pembeli yang memiliki keinginan daya beli untuk membelanjakan. Kesemua faktor tersebut menggambarkan perilaku konsumen. Perilaku 
konsumen dapat dikemukakan sebagai kegiatan individu baik secara langsung maupun tidak langsung terlibat dalam mendapatkan serta menggunakan barang dan jasa (dalam Tarigan, 2007).

Loudon dan Bitta (1998) mendefinisikan perilaku konsumen merupakan aspek penting dalam mengelola strategi pemasaran. Perilaku konsumen merupakan proses keputusan dan aktivitas fisik individu yang digunakan ketika mengevaluasi, mendapatkan, menggunakan atau menentukan barang dan jasa, dalam Farida (2010). Perilaku konsumen adalah studi mengenai proses yang terjadi saat individu atau kelompok penyeleksi, membeli, menggunakan, atau menghentikan pemakaian produk, jasa, ide, atau pengalaman dalam rangka memuaskan keinginan dan hasrat tertentu (Solomon, 1999) dalam bukunya Tjiptono (2004).

Pengertian perilaku konsumen menurut James F. Engel et al, 1968 (dalam Mangkunegara, 2002) yaitu:

"Consumer behavior is defined as the acts of individuals directly involved in obtaining and using services including the decision process that precede and determine these acts" (James F. Engel et al., 1968: 22).

Dari kutipan di atas, perilaku konsumen didefinisikan sebagai tindakan individu yang secara langsung terlibat dalam usaha memperoleh dan menggunakan barang dan jasa termasuk proses pengambilan keputusan yang mendahului dan menentukan tindakan tersebut. Tindakan individu dalam memutuskan untuk membeli barang dan jasa harus melalui proses pengambilan keputusan yang secara langsung terlibat dalam usaha memperoleh dan menggunakan suatu produk.

Salah satu bentuk perintah agama Islam adalah perintah unutk mengenakan busana yang menutup seluruh aurat yang tidak layak untuk dinampakkan pada orang lain yang bukan muhrim. Dari situlah akhirnya muncul apa yang disebut dengan istilah "Busana Muslim". Busana muslimah adalah busana yang sesuai dengan ajaran Islam, dan pengguna gaun tersebut mencerminkan seorang muslimah yang taat atas ajaran agamanya dalam tata cara berbusana. Menurut Imam Al-Fayuni, (107) menegaskan bahwa "busana muslimah adalah suatu pakaian yang dapat menutupi aurat yang sifatnya longgar. Selanjutnya Al-hafiz dan Ibnu Hamzah, yang diterjemahkan oleh Shahab (1986) mengemukakan busana adalah "sebagai pakaian yang menutupi seluruh tubuh, (kecuali yang diperbolehkan tampak)". Busana muslimah modern dalam penelitian ini 
merupakan busana yang sesuai dengan syariat agama namun tetap terlihat modies dengan adanya perubahan dari peradaban saat ini.

Keputusan membeli adalah suatu proses memilih, menyeleksi atau menentukan satu pilihan dari berbagai alternatif dengan cara yang rasional. Hal ini menandakan bahwa dalam pengambilan keputusan individu dihadapkan oleh berbagai alternatif pilihan dan dirinya diharuskan untuk memilih salah satu dari alternatif tersebut. Sehingga keputusan membeli pada konsumen mencakup dua hal atau komponen, yaitu jadi membeli atau tidak jadi membeli.

Keputusan membeli konsumen dapat dipengaruhi oleh berbagai faktor yang dicakup menjadi dua, yaitu faktor internal (persepsi, belajar, memori, motivasi, kepribadian, emosi, sikap, konsep diri, dan gaya diri), dan faktor eksternal (budaya, subbudaya, demografi, status sosial, kelompok acuan, keluarga, dan aktivitas marketing). Dari faktor di atas akan membentuk sikap pada diri individu untuk melakukan pembelian. Faktorfaktor yang mempengaruhi perilaku konsumen dalam penelitian ini meliputi faktor sosial (kelompok acuan dan keluarga), dan faktor psikologis (motivasi, persepsi, pembelajaran, serta keyakinan dan sikap).

Adapun keterkaitan antara perilaku konsumen dengan keputusan membeli yaitu adanya tindakan serta proses psikologis yang mendorong tindakan tersebut pada saat sebelum membeli, ketika membeli, menggunakan, menghabiskan produk dan jasa, serta melakukan kegiatan mengevaluasi. Para pemasar yang memahami perilaku konsumen akan mampu mempengaruhi perilaku konsumen sehingga sesuai dengan apa yang diinginkan oleh pemasar. Oleh karena itu, para pemasar berkewajiban untuk memahami konsumen, mengetahui apa yang dibutuhkan, apa seleranya, dan bagaimana konsumen mengambil keputusan untuk membentuk perilaku membeli guna memperoleh kepuasan yang baik bagi konsumen. Perilaku konsumen dalam hal ini merupakan proses pengambilan keputusan dan kegiatan fisik individu dalam upaya memperoleh dan menggunakan barang dan jasa (evaluasi, memperoleh, menggunakan atau menentukan barang dan jasa). Proses tersebut menunjukkan bahwa dengan adanya perilaku konsumen maka pemasar dapat mengetahui secara jelas proses pengambilan keputusan membeli yang dilakukan konsumen dan pengaruh dari faktor apa saja yang dihadapi konsumen dalam usaha memperoleh busana muslimah modern.

Berdasarkan hal tersebut, maka penelitian ini bertujuan untuk mengatahui faktor apa saja yang paling dominan berpengaruh pada 
konsumen dalam mengambil keputusan membeli busana muslim modern khususnya pada mahasiswi Fakultas Psikologi Universitas Islam Negeri Syarif Hidayatullah Jakarta.

Karena penelitian ini diuji dengan analisis statistik, maka hipotesis yang akan diuji adalah hipotesis mayor dan hipotesis minor, yaitu:

\section{Hipotesis mayor:}

Terdapat pengaruh yang signifikan faktor sosial (kelompok acuan dan keluarga) dan psikologis (motivasi, persepsi, pembelajaran, keyakinan dan sikap) terhadap keputusan membeli busana muslimah modern pada mahasiswi Fakultas Psikologi UIN Jakarta.

\section{Hipotesis minor:}

$\mathrm{H}_{1}$ : Terdapat pengaruh yang signifikan kelompok acuan konsumen terhadap keputusan membeli busana muslimah modern.

$\mathrm{H}_{2}$ : Terdapat pengaruh yang signifikan keluarga konsumen terhadap keputusan membeli busana muslimah modern.

$\mathrm{H}_{3}$ : Terdapat pengaruh yang signifikan motivasi konsumen terhadap keputusan membeli busana muslimah modern.

$\mathrm{H}_{4}$ : Terdapat pengaruh yang signifikan persepsi konsumen terhadap keputusan membeli busana muslimah modern.

$\mathrm{H}_{5}$ : Terdapat pengaruh yang signifikan pembelajaran konsumen terhadap keputusan membeli busana muslimah modern.

$\mathrm{H}_{6}$ : Terdapat pengaruh yang signifikan keyakinan dan sikap konsumen terhadap keputusan membeli busana muslimah modern.

$\mathrm{H}_{7}$ : Terdapat pengaruh yang signifikan usia konsumen terhadap keputusan membeli busana muslimah modern.

\section{METODE}

\section{Populasi dan Sampel}

Populasi dalam penelitian ini yaitu mahasiswi Fakultas Psikologi UIN Syarif Hidayatullah Jakarta tahun akademik 2008/2009 sampai tahun akademik 2014/2015. Jumlah populasi sebanyak 595 orang.

Selanjutnya penulis mengambil sebanyak 200 orang dari populasi tersebut. Adapaun cara pemilihan sampel dilakukan secara non-probability sampling, dimana peluang terpilihnya anggota sampel tidak diketahui. 


\section{Variabel Penelitian}

Variabel dalam penelitian ini adalah sebagai berikut:

Tabel 1

Variabel Penelitian

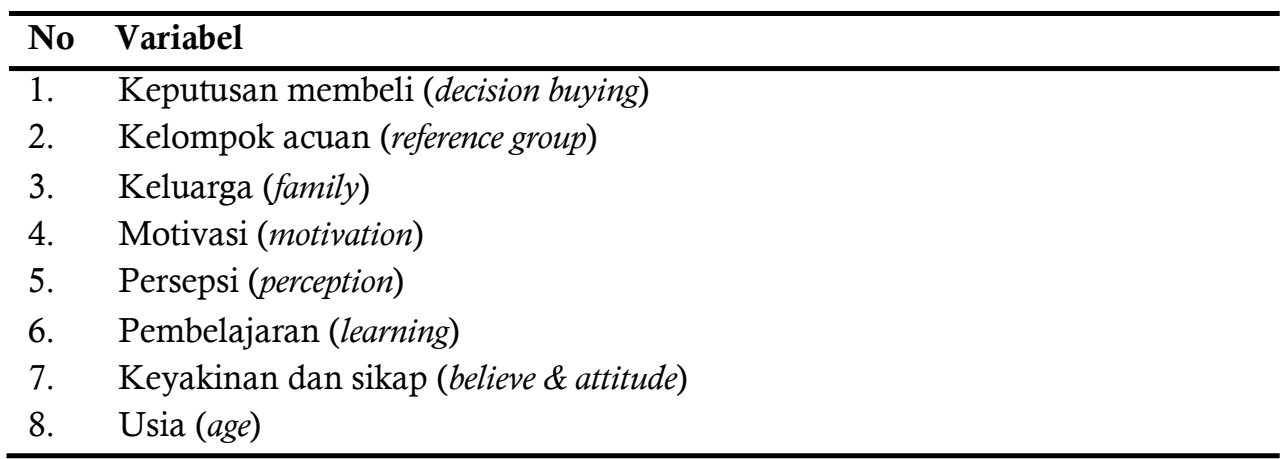

Variabel dependen (outcome variable) dalam penelitian ini adalah keputusan membeli busana muslimah modern, sedangkan variabel lainnya merupakan variabel independen (predictor variable).

\section{HASIL}

Dijelaskan gambaran sampel yang membeli dan tidak membeli pada variabel dependen yaitu keputusan membeli busana muslimah modern. Gambaran subjek dapat dilihat pada tabel di bawah ini.

\section{Tabel 2}

Klasifikasi

\begin{tabular}{lcc}
\hline \multicolumn{1}{c}{ Subjek penelitian } & Jumlah & Persentase \\
\hline Membeli & 46 & 23.0 \\
Tidak membeli & 154 & 77.0 \\
Total & 200 & 100.0 \\
\hline
\end{tabular}

Berdasarkan tabel dapat diketahui bahwa dari 200 subjek mahasiswa Fakultas Psikologi UIN Jakarta, 46 subjek (23\%) menyatakan bahwa mereka membeli busana muslimah modern dan 154 subjek (77\%) menyatakan tidak membeli busana muslimah modern.

Pada tabel selanjutnya digambarkan hasil deskriptif statistik dari setiap variabel yang digunakan pada penelitian ini. 
Tabel 3

Descriptive Statistics

\begin{tabular}{lccccc}
\hline & N & Minimum & Maximum & Mean & Std. Deviation \\
\hline KEL_ACUAN & 200 & 20.58 & 72.29 & 50.0000 & 8.81139 \\
KELUARGA & 200 & 17.27 & 72.95 & 50.0000 & 9.16830 \\
MOTIVASI & 200 & 21.88 & 73.73 & 50.0000 & 9.24653 \\
PERSEPSI & 200 & 9.48 & 74.16 & 50.0000 & 8.78954 \\
BELAJAR & 200 & 21.87 & 75.36 & 50.0000 & 8.80921 \\
YSIKAP & 200 & 21.51 & 76.14 & 50.0000 & 8.93017 \\
USIA & 200 & 19.00 & 24.00 & 21.4550 & 1.25132 \\
Valid N (listwise) & 200 & & & & \\
\hline
\end{tabular}

Berdasarkan tabel di atas diketahui deskripsi statistik pada setiap variabel independen. Kolom $\mathrm{N}$ menjelaskan bahwa sampel pada setiap variabel independen berjumlah 200. Kolom minimum dan maximum menjelaskan nilai minimum dan maximum pada setiap variabel independen. Dilihat dari minimum diketahui persepsi memiliki nilai terendah dan berdasarkan kolom maximum diketahui variabel keyakinan dan sikap memiliki nilai tertinggi dengan masing-masing nilai mean 50 dan standar deviasi 9.

\section{Analisis Regresi Logistik Variabel Penelitian}

Penulis menguji hipotesis dengan teknik analisis regresi logistik menggunakan software SPSS. Dalam pengolohan data menggunakan regresi logistik penulis melihat besaran Nagelkerke R Square untuk mengetahui berapa persen (\%) varians variabel dependen yang dijelaskan oleh variabel independen, melihat secara keseluruhan apakah variabel independen berpengaruh secara signifikan terhadap variabel dependen (uji model regresi logistik) dan melihat koefisien regresi dalam bentuk logit, odd dan probability.

\section{Uji Model Regresi Logistik}

Penulis melihat besaran Nagelkerke R Square untuk mengetahui berapa persen (\%) varians variabel dependen dalam satuan logit yang dijelaskan oleh variabel independen (Connell, 2006). Selanjutnya untuk tabel Nagelkerke R Square, dapat dilihat pada tabel berikut: 
Tabel 4

Nagelkerke R Square

\begin{tabular}{rccc}
\hline Step & -2log likelihood & $\begin{array}{c}\text { Cox \& snell R } \\
\text { square }\end{array}$ & $\begin{array}{c}\text { Nagelkerke } \mathbf{r} \\
\text { square }\end{array}$ \\
\hline 1 & $156.142^{\mathrm{a}}$ & .258 & .390 \\
\hline
\end{tabular}

Penulis melihat perolehan hasil dari tabel model summary pada bagian Nagelkerke $R$ Square untuk melihat proporsi varian dari logit membeli. Penulis melihat nilai Nagelkerke $R$ Square karena nilai Nagelkerke $R$ Square adalah pengukuran ulang dari proporsi varian dari logit membeli yang diperoleh dari tabel Cox \& Snell R Square sehingga mendapatkan batas nilai 1.0 (Connell, 2006). Oleh karena itu nilai Nagelkerke $R$ Square bisa ditafsirkan seperti proporsi varian pada analisis regresi linier pada satuan logit. Bagi pembaca yang terbiasa dengan nilai $R$ Square pada regresi linier maka pada penelitian ini lebih baik melihat nilai Nagelkerke $R$ Square karena koefisiennya memiliki rentangan hingga 1.0.

Dari tabel 4 dapat dilihat bahwa perolehan Nagelkerke $R$ Square sebesar 0.390 atau $39 \%$. Hal ini menunjukkan bahwa besarnya proporsi varian dari logit membeli yang bisa dijelaskan oleh enam variabel independen yaitu kelompok acuan $\left(\mathrm{X}_{1}\right)$, keluarga $\left(\mathrm{X}_{2}\right)$, motivasi $\left(\mathrm{X}_{3}\right)$, persepsi $\left(\mathrm{X}_{4}\right)$, pembelajaran $\left(\mathrm{X}_{5}\right)$, keyakinan dan sikap $\left(\mathrm{X}_{6}\right)$, usia $\left(\mathrm{X}_{7}\right)$ sebesar $39 \%$ dan sisanya yaitu $61 \%$ dijelaskan oleh variabel lain diluar penelitian ini.

Untuk menilai ketepatan penggunaan model regresi logistik yaitu untuk mengetahui apakah model regresi logistik sudah sesuai dengan data yang diperoleh maka dilakukan pengujian model fit seperti yang disarankan oleh Hosmer dan Lemeshow (2000). Selanjutnya, peneliti menganalisis dampak dari seluruh variabel independen terhadap keputusan membeli. Adapun hasilnya dapat dilihat pada tabel berikut:

Tabel 5

Hosmer And Lemeshow Test

\begin{tabular}{rcrl}
\hline Step & Chi-square & Df & Sig. \\
\hline 1 & 12.917 & 8 & .115 \\
\hline
\end{tabular}

Dari tabel di atas diketahui bahwa pada penelitian ini model Chisquare memiliki derajat kebebasan 8 , nilai 12.917 , dan signifikansi 0.115 $(>0.05)$ ini menunjukkan bahwa model sudah $f i t$, di mana mengindikasikan bahwa model regresi logistik sesuai data. Dengan kata lain dapat dikatakan 
bahwa hipotetsis nihil yang menyatakan tidak ada pengaruh yang signifikan dari seluruh variabel independen terhadap keputusan membeli ditolak. Artinya, ada pengaruh yang signifikan dari kelompok acuan, keluarga, motivasi, persepsi, pembeljaran, keyakinan dan sikap serta usia terhadap keputusan membeli busana muslimah modern.

\section{Signifikansi Variabel}

Langkah selanjutnya adalah melihat koefisien regresi dari setiap variabel independen. Jika sig $<0.05$, maka koefisien tersebut signifikan yang berarti bahwa variabel independen tersebut memiliki dampak yang signifikan terhadap keputusan membeli. Adapun koefisien regresi yang dihasilkan seperti pada tabel 6 berikut.

\section{Tabel 6}

Koefisien Regresi

\begin{tabular}{rlrrrrrr}
\hline & & B & S.E. & Wald & df & Sig. & $\operatorname{Exp(B)}$ \\
\hline \multirow{3}{*}{ Step $1^{\text {a }}$} & Constant & -13.838 & 4.152 & 11.109 & 1 & .001 & .000 \\
& KEL_ACUAN & .051 & .032 & 2.521 & 1 & .112 & 1.052 \\
& KELUARGA & .003 & .029 & .013 & 1 & .908 & 1.003 \\
& MOTIVASI & .049 & .028 & 2.993 & 1 & .084 & 1.050 \\
& PERSEPSI & -.021 & .027 & .584 & 1 & .445 & .980 \\
& BELAJAR & .053 & .032 & 2.703 & 1 & .100 & 1.055 \\
& YSIKAP & .099 & .030 & 10.704 & 1 & .001 & 1.106 \\
& USIA & .174 & .171 & 1.034 & 1 & .309 & 1.190 \\
\hline
\end{tabular}

a. Variable(s) entered on step 1: KEL_ACUAN, KELUARGA, MOTIVASI, PERSEPSI, BELAJAR, YSIKAP, USIA

Penjelasan regresi logistik dijelaskan dalam bentuk logit, odds dan probability. Logit atau log odds adalah log dari ratio dua probability. Odds adalah ratio dari dua probability. Odds ratio yaitu ratio dua odds dan persen perubahan odds ratio adalah nilai persen perubahan pada odds ratio. Probability adalah peluang terjadinya perilaku dimana dalam penelitian ini adalah peluang terjadinya keputusan membeli.

Pertama, penjelasan nilai koefisien regresi dalam satuan logit. Logit memiliki rentang nilai $-\infty$ (negatif tidak terhingga) sampai dengan $+\infty$ (positif tidak terhingga). Berdasarkan nilai pada tabel 4.6, persamaan regresi dalam satuan logit adalah sebagai berikut: (*signifikan). 


$$
\begin{aligned}
\frac{\mathrm{pi}_{\mathrm{i}}}{\operatorname{Ln}(1-\mathrm{Pi})}= & -13.838+0.051 \text { kel_acuan }+0.003 \text { keluarga }+0.049 \\
& \text { motivasi }-0.021 \text { persepsi }+0.053 \text { pembelajaran }+0.099 \\
& \text { keyakinan \& sikap }{ }^{*}+0.174 \text { usia }
\end{aligned}
$$

Berdasarkan hasil uji signifikansi (uji Wald) pada setiap variabel independen dengan taraf signifikansi 5\% koefisien keyakinan \& sikap signifikan, sedangkan yang lainnya tidak, hal ini menunjukkan bahwa dari enam hipotesis minor terdapat satu yang signifikan.

Koefisien regresi dalam satuan logit yang diperoleh masing-masing variabel independen adalah sebagai berikut:

1. Variabel kelompok acuan. Diperoleh nilai koefisien regresi sebesar 0.051 dengan sig. $0.112($ sig $>0.05)$ artinya tidak ada pengaruh yang signifikan kelompok acuan konsumen terhadap logit keputusan membeli busana muslimah modern.

2. Variabel keluarga. Diperoleh nilai koefisien regresi sebesar 0.003 dengan sig. 0.908 (sig $>0.05$ ) artinya tidak ada pengaruh yang signifikan keluarga konsumen terhadap logit keputusan membeli busana muslimah modern.

3. Variabel motivasi. Diperoleh nilai koefisien regresi sebesar 0.049 dengan sig. 0.084 ( $\mathrm{sig}>0.05$ ) artinya tidak ada pengaruh yang signifikan motivasi konsumen terhadap logit keputusan membeli busana muslimah modern.

4. Variabel persepsi. Diperoleh nilai koefisien regresi sebesar -0.021 dengan sig. 0.445 (sig $>0.05$ ) artinya tidak ada pengaruh yang signifikan persepsi konsumen terhadap logit keputusan membeli busana muslimah modern.

5. Variabel pembelajaran. Diperoleh nilai koefisien regresi sebesar 0.053 dengan sig. 0.100 (sig $>0.05)$ artinya tidak ada pengaruh yang signifikan pembelajaran konsumen terhadap logit keputusan membeli busana muslimah modern.

6. Variabel keyakinan dan sikap. Diperoleh nilai koefisien regresi sebesar 0.099 dengan sig. $0.001 \quad($ sig $<0.05)$ artinya ada pengaruh signifikan keyakinan dan sikap terhadap logit keputusan membeli busana muslimah modern. Jadi, semakin tinggi keyakinan dan sikap maka semakin tinggi logit keputusan membeli dan setiap kenaikan satu unit pada variabel keyakinan dan sikap berasosiasi dengan kenaikan sebesar 0.099 logit keputusan membeli.

7. Variabel usia. Diperoleh nilai koefisien regresi sebesar 0.174 dengan sig. 0.309 (sig $>0.05$ ) artinya tidak ada pengaruh yang signifikan usia konsumen terhadap logit keputusan membeli busana muslimah modern. 
Tabel 7

Proporsi Varians Untuk Masing-masing Variabel Independen

\begin{tabular}{llcc}
\hline No & Variabel independen & Nagelkerke R Square & $\begin{array}{c}\text { Pertambahan } \\
\text { Nagelkerke R Square }\end{array}$ \\
\hline 1. & Kelompok acuan & 0.248 & 0.248 \\
2. & Keluarga & 0.282 & 0.034 \\
3. & Motivasi & 0.301 & 0.019 \\
4. & Perserpsi & 0.301 & 0 \\
5. & Pembelajaran & 0.306 & 0.005 \\
6. & Keyakinan \& sikap & 0.384 & 0.078 \\
7. & Usia & 0.390 & 0.006 \\
\hline \multicolumn{2}{l}{ Jumlah } & 0.390 \\
\hline
\end{tabular}

Nilai Nagelkerke $R$ Square yang dihasilkan pada tabel 4.7, dapat ditafsirkan seperti nilai $\mathrm{R}$ Square pada regresi linier karena Nagelkerke $R$ Square dinyatakan dalam satuan logit. Namun pada penelitian umumnya, jarang dijelaskan proporsi varian pada masing-masing variabel independen seperti yang peneliti lakukan.

Dilihat dari besarnya pertambahan nilai Nagelkerke $R$ Square yang dihasilkan dapat disimpulkan bahwa dari keenam variabel independen yaitu: kelompok acuan, keluarga, motivasi, persepsi, pembelajaran, keyakinan dan sikap dapat diketahui variabel independen yang memberikan sumbangan dari yang terbesar hingga yang terkecil, kelompok acuan dengan nilai Nagelkerke $R$ Square sebesar 0.248 , keyakinan dan sikap dengan nilai Nagelkerke $R$ Square sebesar 0.078, keluarga dengan nilai Nagelkerke $R$ Square sebesar 0.034, motivasi dengan nilai Nagelkerke $R$ Square sebesar 0.019 , usia dengan nilai Nagelkerke $R$ Square sebesar 0.006, pembelajaran dengan nilai Nagelkerke R Square sebesar 0.005, terakhir persepsi dengan nilai Nagelkerke $R$ Square sebesar 0 .

Berdasarkan hasil analisis data penelitian maka kesimpulan yang dapat diambil dari penelitian ini adalah: "terdapat pengaruh yang signifikan dari faktor sosial (kelompok acuan dan keluarga) dan faktor psikologis (motivasi, persepsi, pembelajaran, keyakinan dan sikap) konsumen terhadap keputusan membeli busana muslimah modern pada mahasiswi Fakultas psikologi UIN Jakarta". Berdasarkan proporsi varians seluruhnya, logit keputusan membeli yang dipengaruhi variabel independen (sosial dan psikologis) adalah sebesar $39 \%$. 


\section{DISKUSI}

Perkembangan fashion muslimah mengalami peningkatan yang luar biasa. Hal ini disebabkan adanya kesadaran masyarakat muslim akan kewajibannya menutup aurat. Peran dari para tokoh agama, ustadz/ustadzah yang mensyiarkan kewajiban menutup aurat dari mulai tingkat sekolah dasar hingga perguruan tinggi juga majelis ilmu yang tersebar sampai ke pelosok sangat berpengaruh terhadap perkembangan busana muslimah. Hal ini menjadi peluang yang baik bagi para pelaku dibidang fashion untuk memenuhi kebutuhan masyarakat terhadap busana muslimah. Mulai dari designer papan atas hingga pedagang di pasar tradisional bersaing menarik konsumen untuk melakukan perilaku untuk membeli. Penelitian ini dilakukan dengan tujuan untuk mengetahui faktorfaktor yang mempengaruhi konsumen terhadap keputusan membeli busana muslimah modern dari sudut pandang sosial dan psikologis konsumen sehingga dapat mengetahui keinginan dan kebutuhan konsumen dalam membeli busana muslimah modern. Hasil penelitian ini menunjukkan bahwa secara keseluruhan sosial, dan psikologis secara signifikan berpengaruh terhadap keputusan membeli busana muslimah modern.

Dimensi kelompok acuan memberikan sumbangan pengaruh sebesar $24.8 \%$ dengan nilai koefisien regresi sebesar 0.052 dengan sig. 0.107 (sig $>0.05$ ), yang berarti secara positif mempengaruhi keputusan membeli busana muslimah modern dengan keriteria tidak signifikan. Hal ini berarti semakin tinggi pengaruh kelompok acuan seseorang maka semakin tinggi keputusan membeli busana muslimah modern. Dalam penelitian ini kelompok acuan memberikan standar (norma) dan nilai yang dapat menjadi perspektif penentu mengenai bagaimana seseorang berpikir atau berperilaku (Engel, Blackwell, dan Miniard, 2002). Hal ini menunjukkan bahwa kelompok acuan memberikan penutan kepada anggotanya untuk membentuk perilaku khususnya perilaku dalam keputusan membeli.

Dimensi keluarga memberika sumbangan pengaruh sebesar $3.4 \%$ dengan nilai koefisien regresi sebesar 0.010 dengan sig. 0.737 (sig $>0.05$ ), yang berarti secara positif mempengaruhi keputusan membeli busana muslimah modern dengan keriteria tidak signifikan. Hal ini berarti semakin tinggi peran keluarga dalam mempengaruhi maka semakin tinggi keputusan membeli busana muslimah modern. Dalan penelitian ini adanya interaksi dalam keluarga ketika melakukan proses membeli, sangat menunjang terjadinya proses keputusan membeli suatu produk. Tiap anggota keluarga 
memiliki peran masing-masing dalam mempengaruhi tingkah laku membeli. Keluarga merupakan organisasi pembelian konsumen yang paling penting dalam masyarakat, salah satu contoh yang paling dominan adalah keterlibatan suami-istri dalam proses pembelian (Philip Kotler, 2010).

Dari variabel sosial dengan dua dimensi didalamnya, masing-masing memberikan pengaruh yang berbeda terhadap keputusan membeli busana muslimah modern. Kelompok acuan memberikan pengaruh sebesar yaitu $24.8 \%$ dengan keriteria tidak signifikan. Keluarga memberikan pengaruh sebesar 3.4\% dengan kriteria tidak signifikan. Penelitian ini tidak sejalan dengan penelitian yang dilakukan oleh Firda Amalia (2010), yang meneliti tentang "Analisis pengaruh faktor budaya, sosial, pribadi, dan psikologis terhadap keputusan membeli minuman penambah tenaga cair merek M-150 di Semarang. Dalam penelitian tersebut menunjukkan bahwa ada pengaruh yang signifikan dari sosial konsumen terhadap keputusan membeli minuman penambah tenaga cair merek M-150 di Semarang. Adanya hasil yang berbeda dengan penelitian yang dilakukan oleh penulis, mungkin dikarenakan adanya sampel yang berbeda. Penulis melakukan penelitian dengan mengkhususkan sampel wanita dengan penelitian membeli busana muslimah modern, sedangkan penelitian yang dilakukan oleh Firda mengkhususkan sampel pada laki-laki dengan penelitian membeli minuman cair penembah tenaga.

Dimensi motivasi memberikan sumbangan pengaruh sebesar $1.9 \%$ dengan nilai koefisien regresi sebesar 0.042 dengan sig. 0.135 (sig>0.05), yang berarti bahwa variabel motivasi secara positif mempengaruhi logit keputusan membeli busana muslimah modern tetapi tidak signifikan. Jadi, semakin tinggi motivasi konsumen maka semakin tinggi logit keputusan membeli busana muslimah modern. Dalam penelitian ini adanya dorongan (drive) yang berasal dari dalam individu kemudian dorongan tersebut menghasilkan kebutuhan dengan intensitas yang kuat. Kebutuhan seseorang untuk membentuk perilaku untuk membeli.

Dimensi persepsi memberikan sumbangan pengaruh sebesar $0 \%$ dengan nilai koefisien regresi sebesar -0.021 dengan sig. 0.430 (sig>0.05), yang berarti bahwa variabel persepsi secara negatif mempengaruhi logit keputusan membeli busana muslimah modern tetapi tidak signifikan. Jadi, semakin tinggi persepsi maka semakin rendah logit keputusan membeli busana muslimah modern. Dalam penelitian ini persepsi didefinisikan sebagai suatu proses yang dilakukan individu untuk memilih, mengatur, dan menafsirkan stimuli ke dalam gambar yang berarti dan masuk akal 
mengenai dunia (Schiffman dan Kanuk, 2008). Adanya proses yang dilakukan seseorang akan membentuk suatu perilaku yang diambil dalam keputusan membeli.

Dimensi pembelajaran memberikan sumbangan pengaruh sebesar $0.5 \%$ dengan nilai koefisien regresi sebesar 0.054 dengan sig. 0.097 (sig $>0.05$ ), yang berarti bahwa variabel pembelajaran secara positif mempengaruhi logit keputusan membeli busana muslimah modern tetapi tidak signifikan. Jadi, semakin tinggi pembelajaran maka semakin tinggi logit keputusan membeli busana muslimah modern. Dalam penelitian ini pembelajaran merupakan suatu perubahan dalam perilaku seseorang yang timbul dari pengalaman (Kotler dan Armstrong, 2008). Adanya proses bagi konsumen untuk terus menerus berkembang dan berubah karena adanya pengetahuan yang baru diperoleh atau dari pengalaman yang dialami sendiri. Hal tersebut akan membentuk konsumen untuk menunjukkan perilaku yang baru dalam hal keputusan membeli.

Dari variabel psikologis terdapat empat dimensi yang mempengaruhi konsumen terhadap keputusan membeli busana muslimah modern. Tiga diantaranya memberikan pengaruh yang berbeda, motivasi memberikan pengaruh sebesar $1.9 \%$, dengan keriteria tidak signifikan. Persepsi memberikan pengaruh sebesar $0 \%$, dengan keriteria tidak signifikan. Dan pembelajaran memberikan pengaruh sebesar $0.5 \%$, dengan keriteria tidak signifikan. Namun ada satu dimensi yang memiliki kriteria yang signifikan terhadap keputusan membeli yaitu dimensi keyakinan dan sikap.

Dimensi keyakinan dan sikap memberikan sumbangan pengaruh sebesar $7.8 \%$ dengan nilai koefisien regresi sebesar 0.101 dengan sig. 0.001 $($ sig<0.05). Pengaruh keyakinan dan sikapbernilai positif, artinya semakin tinggi tingkat keyakinan dan sikap seseorang, maka semakin tinggi keputusan membeli busana muslimah modern. Dengan adanya keyakinan dan sikap yang positif dari dalam diri konsumen, akan membentuk perilaku dalam hal keputusan membeli busana muslimah modern. Hal ini sesuai dengan hasil penelitian terdahulu yang dilakukan oleh Feri Aditia Suhaji (2010) dengan penelitian "faktor-faktor yang mempengaruhi keputusan pembelian baju MINT di counter Java Mall Semarang", yang menyimpulkan bahwa keyakinan dan sikap mempengaruhi keputusan membeli busanan muslimah modern secara positif. Sama halnya penelitian yang dilakukan oleh Yohanes Suhari (2008) yang mengatakan bahwa sikap dan kepercayaan berpengaruh positif terhadap keputusan pembelian. 
Dari beberapa teori dan penelitian yang ada dijelaskan bahwa Sikap merupakan suatu penilaian kognitif seseorang terhadap suka atau tidak suka, perasaan emosional yang tindakannya cenderung ke arah berbagai objek atau ide. Sikap sangat mempengaruhi keyakinan, begitu pula sebaliknya, keyakinan mempengaruhi sikap. Dalam perilaku konsumen, sikap dan keyakinan sangat berpengaruh dalam menentukan suatu produk, merek, dan pelayanan. Sikap dan keyakinan konsumen terhadap suatu produk atau merek dapat diubah melalui komunikasi yang persuasif dan pemberian informasi yang efektif kepada konsumen (Mangkunegara, 2005).

Berikut ini adalah saran yang dapat peneliti berikan:

1. Berdasarkan hasil penelitian regresi logistik, nilai Nagelkerke $R$ Square memberikan sumbangan sebesar $39 \%$ dimana variabel yang menunjukkan signifikansi terhadap keputusan membeli busana muslimah modern yaitu variabel keyakinan dan sikap. Untuk nilai proporsi varian sumbangan efektif dari hasil penelitian, faktor keyakinan dan sikap yang mempengaruhi keputusan membeli busana muslimah modern menunjukkan pengaruh secara keseluruhan sebesar $7.8 \%$ dan selebihnya dipengaruhi oleh variabel lain. Kelompok acuan memberikan sumbangan terbesar dalam varian logit keputusan membeli yaitu sebesar $24.8 \%$. Untuk penelitian selanjutnya disarankan agar melakukan penelitian untuk menguji faktor lain yang mempengaruhi keputusan membeli busana muslimah modern seperti marketing strategic (Engel \& Balwel, 2008), promotion mix (Kotler \& Armstrong, 2007) dan beberapa variabel demografi, seperti pendapatan, profesi dan lain sebagainya. Faktor pribadi (Kotler \& Armstrong, 2007) penulis sarankan untuk digunakan karena dilihat dari aspek-aspek (status sosial, pendapatan, dan pekerjaan). Dengan mempertimbangkan variabel tersebut, diharapkan penelitian selanjutnya akan lebih menyempurnakan hasil dalam penelitian ini.

2. Pada penelitian ini sampel yang digunakan yaitu mahasiswa berjumlah 200 orang. Dengan bertambahnya variabel lain yang akan diteliti, maka jumlah item pun akan bertambah. Jumlah sampel harus ditambah dan disesuaikan dengan kebutuhan penelitian. Penyesuaian karakteristik sampel diharapkan akan memberikan data yang lebih representatif. Untuk penelitian selanjutnya diharapkan responden memiliki karakteristik yang sesuai dan lebih representatif, seperti hijabber community. 
3. Penelitian ini bertemakan keputusan membeli busana muslimah modern. Secara tema, ranah penelitian ini memiliki cakupan yang luas, maka untuk penelitian selanjutnya diharapkan peneliti mempersempit ranah penelitian agar hasil yang didapat lebih spesifek, misalnya fashion hijab muslimah merek A atau B.

4. Hasil penelitian menunjukkan bahwa variabel keyakinan dan sikap (believe \& attitute) berpengaruh secara signifikan $(\mathrm{p}<0.005)$ terhadap keputusan membeli busana muslimah moden. Saran yang dapat disampaikan adalah bagi pemasar yang bergerak dibidang fashion muslim agar mampu memperhatikan kondisi psikologis konsumen sehingga dapat menghasilkan produk yang sesuai dengan kebutuhan dan keinginan konsumen. Dalam hal ini produsen dituntut untuk menghasilkan produk yang berkualitas dengan harga jual terjangkau dan bagian marketing harus tepat sasaran. Produsen harus selalu memperhatikan trend fashion yang diinginkan sehingga konsumen memiliki sikap dan keyakinan positif agar tertarik untuk melakukan pembelian busana muslimah modern.

\section{DAFTAR PUSTAKA}

Amalia, Firda. (2011). Analisa pengaruh faktor budaya, sosial, pribadi dan psikologis terhadap keputusan pembelian minuman penambah tenaga cair merek M-150 di Semarang. Skripsi. Universitas Diponegoro.

Amiruddin. (2011). Kriteria busana muslimah. Jakarta: Mizan

Amstrong, G. \& Kotler, P.(2008). Prinsip-prinsip pemasaran. Cetakan Pertama. Jakarta: Erlangga.

Angipora, Marius P. (2002). Dasar-dasar pemasaran. Jakarta: PT. Raja Grafindo Persada.

Azizah, Nora. (2014). Indonesia berpeluang besar jadi tren fesyen muslim dunia. Diunduh tanggal 9 Juli 2014. http://www.republika.co.id

Bukti A. Tarigan. (2007). Beberapa faktor yang berpengaruh terhadap perilaku konsumen dalam pemilihan produk. Jurnal. Media Unika Vol. 2, No. 20. Tahun 2007.

David W. Hosmer, Jr., Stanley Lemeshow. (2004). Applied logistic regression. California: Sage Publication, Inc.

Dian.(2013). Busana muslimah. Diunduh tanggal 28 November 2014. http://diianchibi.wordpress.com

Engel, J.F., Blackwell, R.D., Miniard, P.W. (2002). Perilaku konsumen. Edisi Keenam, Binapura Aksara, Jakarta. 
Delia, Fratu. (2011). Factors of influence and change in the tourism consumer behaviour. Bulletin of the Transilvania University of Bravos.Vol. 4, (53). No. 1. Tahun 2011.

Hartono. (2012). Kemenperin gelar pameran produk busana muslim. Diunduh tanggal 8 Maret 2014. http://www.kemenperin.go.id

Kotrler, P. (2008). Manajemen pemasaran. Edisi kedua belas, Jilid 2.Jakarta : PT. Indeks.

Kotler, P., \& Armstrong, G. (1997). Dasar-dasar pemasaran, Edisi Bahasa Indonesia. Jakarta: Prenhallindo.

Kotler, P., \& Keller, K. (2010). Manajemen pemasaran. Jakarta: Indeks

Mangkunegara, A,P,. (2005). Perilaku konsumen. Bandung: PT Eresco Bandung.

Menard, S. (2002). Applied logistic regression analysis (2nd ed). California: Sage Publication, Inc.

Mowen, C. J. \& Minor, M. (2002). Perilaku konsumen, Edisi kelima (terjemahan). Jakarta: Erlangga.

Mowen, C.J. \& Mimor M., (2002). Perilaku konsumen. Edisi Kelima (terjemahan). Jakarta: Penerbit Erlangga.

Mowen, J. C., \& Minor, M., (2002), Consumer behaviour. Fifth Edition, Printice Hall, Upper Saddle Rive, New Jersey.

Osborn, J. (2008). Best practices in quantitative methods: 24 Binary logistic regression. California: Sage Publication, Inc.

Pampel, F.C. (2000). Logistic regression: A primer. SAGE University papers series on quantitative applications in the social science, 07-132. Thousand Oaks, CA: Sage.

Prasetijo \& Ihalauw, J. (2005). Perilaku konsumen. Yogyakarta. ANDI

Setiadi, Nugroho J. (2008). Perilaku konsumen: perspektifkontemporer pada motif, tujuan, dan keinginan konsumen. Edisi Revisi, Cetakan ke-4. Jakarta: Kencana.

Schiffman, Leon G. \& Kanuk, L.L. (2008). Consumer behavior. Seventh Edition. London : Prentice-Hall International (UK) Limited. 
